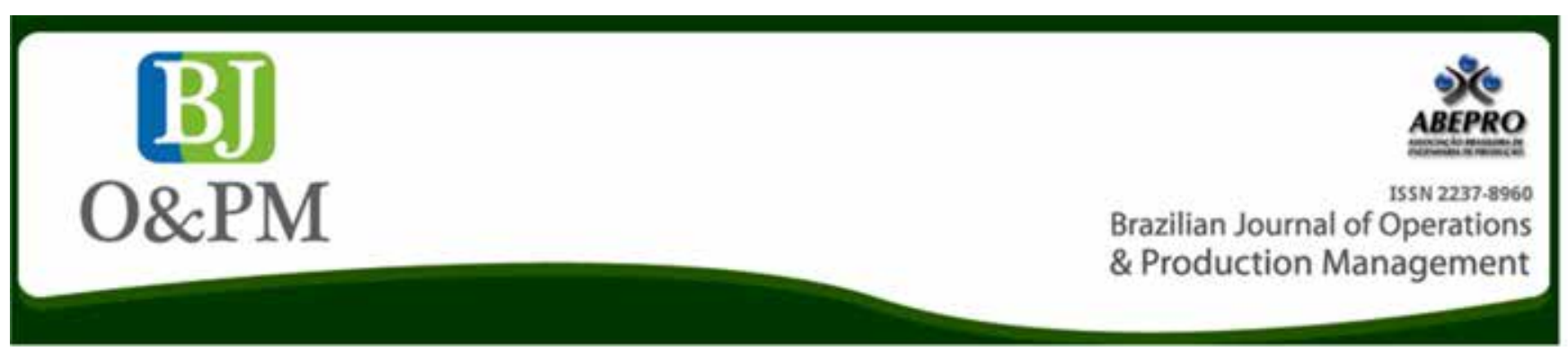

\title{
STRATEGY FOR THE DEVELOPMENT OF AGRICULTURAL MACHINERY: IMPORTANCE OF PATENT ANALYSIS
}

\section{Franco da Silveira}

franco.da.silveira@hotmail.com Federal University of Rio Grande do Sul - UFRGS, Porto Alegre, Rio Grande do Sul, Brazil.

\section{Filipe Molinar Machado}

fmacmec@gmail.com

Federal University of Santa Maria -

UFSM, Santa Maria, Rio Grande do Sul, Brazil.

\section{Leonardo Nabaes Romano} romano@mecanica.ufsm.br Federal University of Santa Maria UFSM, Santa Maria, Rio Grande do Sul, Brazil.

\section{Fernando Gonçalves Amaral} amaral@producao.ufrgs.br Federal University of Rio Grande do Sul - UFRGS, Porto Alegre, Rio Grande do Sul, Brazil.

\section{Janis Elisa Ruppenthal}

profjanis@gmail.com

Federal University of Santa Maria UFSM, Santa Maria, Rio Grande do Sul, Brazil.

\begin{abstract}
During the product development, patents help identify new project opportunities and, if well analyzed, can reveal technical strategies in terms of how countries, companies, and universities link patents and product development. In the context of the agricultural machinery sector there is a complexity in the integration of data from patents with the stages of development conceptions. In this context, the article aims to present how the information obtained from a patent bank can be used for the development of agricultural machinery. As a methodology, the Systematic Bibliographic Review was selected to identify and relate strategies that add value throughout the agricultural machinery project. As a result, research has shown that the use of patent information can assist in the development of agricultural machinery from technical data. In addition, patents are characterized as a valuable source of technological information, as it is inexpensive and capable of feeding a company in its own research activity and in the development of new products. It is concluded that the information from patents, suggested as strategies in the model of agricultural machinery development, allows for managerial and technical decisions aimed at improving products. Finally, the research contributed to fill the information gap between patents and the development of agricultural machinery, a diffusion of data that, if well connected, can promote a competitive differential in companies.
\end{abstract}

Keywords: Agricultural Machinery; Product Development; Patents. 


\section{INTRODUCTION}

The importance of patent analysis is related to the statistical, analytical and comparative methods that are used to examine the information contained in a patent document and thus is widely applied in research and technological development capacity of countries and companies (Pyng et al., 2012). In addition, patents are necessary to identify technological trends and thus help tailoring technology development planning because they provide a general understanding of the historical development of a product to its present stage (Kim et al., 2016). It is on the basis of this completeness that data, information and technological knowledge are usually obtained or created, developed, accumulated and kept secret by the companies that own or hold them, and may or may not be protected by an intellectual property regime ( $\mathrm{Di}$ Blasi, 2005; Carrara and Russo, 2017).

According to Choi and Kim (2017), there is largely no understanding in terms of how patents are used by companies, although a vast amount of data is available on the number of patents companies hold or are in the filing process. For Sichelman (2010), patent policy has a significant responsibility in the relationship between market share and patent use. The author states that new policies should be developed to encourage the early patenting and thus facilitate the expansion of companies in the competitive market. However, there is a gap between developing a patent and making use of patent information that has already been registered for better identifying strategies in the development of new technological products (Pereira et al., 2017).

For Livotov (2015), the situation in the planning and execution of innovation projects within industrial companies presents considerable disadvantages, such as the lack of tools that help in the systematic definition of tasks for innovation in the short term and that compromise the reliability of market success forecasting with concepts of new products in the initial stages (innovation process). Turner (2018) states that many innovative products are complex; therefore, they require multiple complementary inputs that enable the creation of innovation environments. Thus, a company that seeks to innovate constantly needs to adapt technologies to profit from its innovation and may not be sure what adaptations are needed. Despite the best efforts to reduce the risk of failure, most industrial innovation initiatives offer only incremental improvements compared to products on the market (Livotov, 2015). Thus, attempts to incorporate patents in the development of new products require maturity on the part of companies so that in the future they will offer significant competitive advantages (Jou, 2018).

As patents play key roles in protecting the new technology or product, the competitive advantage derived from patenting should reflect company performance (Maresch et al., 2016; Silveira et al., 2018). Thus, from the use of a Referenced Model, called by the Agricultural Machinery Model MR-PDMA, the article identifies forms and activities in the model for the process of using information from patents in product design. The research is important because it seeks to deepen the understanding of information, industrial secrecy and know-how, especially with regard to the agricultural machinery sector. More specifically, it seeks to identify elements that influence the generation of information in design requirements.

The article was structured in four different sections, in addition to this introduction. Section 2 presents the overview of patents as a source of technological information and the Reference Model for the Development of Agricultural Machines. In section 3, we present the methodological approach that was used in the study. Section 4 presents the results and their respective discussions. Finally, in Section 5 , the conclusions of the research are presented along with the references, limitations found, and proposals to carry out future work.

\section{THEORETICAL BACKGROUND}

\section{Patents as Group of Technological Information}

According to Law No. 9,279, enacted in 1996, the patent is a temporary title to an invention or utility model, granted by the State, to inventors, authors, natural or legal persons having rights over creation (De-Carli et al., 2017). In Brazil, according to Law No. 6,404, of 1976, of Corporations, the heading "Patent" should be classified in the Balance Sheet, capitalized as Fixed Assets and, subsequently, have its monetary balance amortized over the term of the right. The patent is a competitive resource available to organizations, due to the domination of the monopolistic exploitation of a given product or production process, a privilege that is capable of creating or adding value to the wealth of companies and their partners (Ferreira et al., 2009). It is important to highlight that companies evaluate intellectual property rights and the quality of patent documents to develop innovative products and discover cutting-edge technological trends (Trappey et al., 2012).

Patent documents and their information have different purposes, such as: (i) securing intellectual property rights; ii) being indicators of Science, Technology and Innovation; and iii) being used as an alternative source of technological information. As a source of technological information, patent documents form food channels for the strategic planning of companies in the pre-product development phase (Front End) in order to guide top management in their market analysis and better manage efforts in the product development 
phase (Gama et al., 2016). Another methodology adopted by companies that need technical patent data to avoid strategic and inventive problems is the Invention Problem Solving Theory (Maleski and Rovai, 2015).

Other advantages are related to the coverage of all technological fields; access to complete documents that are centralized in national or regional patent offices, by electronic means; in the indexing of documents through the International Patent Classification (IPC), which facilitates the retrieval of information; internationally standardized format, by means of a standardized configuration of a set of structured data in specific numbered fields; and describing the content sufficiently so that a person skilled in the art area of the invention can reproduce it (Mayerhoff, 2007). From the information contained in patent documents it is possible to identify different mechanisms that encourage the development of technologies (De-Carli et al., 2017). Table 1 presents 11 conditions that are possible to achieve with patent information.

Table 1. Different mechanisms for the use of patents

\begin{tabular}{|c|c|}
\hline Element & Description of the Mechanism \\
\hline 1 & $\begin{array}{l}\text { The state of the art, where the stage of development } \\
\text { of a certain technology is verified. }\end{array}$ \\
\hline 2 & $\begin{array}{l}\text { Emerging technologies, technology trends, patenting } \\
\text { trends, and potential strategic areas of research. }\end{array}$ \\
\hline 3 & $\begin{array}{c}\text { Existing and available technologies for solving a } \\
\text { specific technological problem as well as alternative } \\
\text { technologies. }\end{array}$ \\
\hline 4 & $\begin{array}{l}\text { Opportunity to create new products and processes } \\
\text { and to improve existing products and processes. }\end{array}$ \\
\hline 5 & $\begin{array}{c}\text { Technologies already developed in order to avoid } \\
\text { duplicity of work and wasted investments in research } \\
\text { and development (P\&D). }\end{array}$ \\
\hline 6 & $\begin{array}{l}\text { Technologies protected to avoid infringement of } \\
\text { industrial property rights. }\end{array}$ \\
\hline 7 & $\begin{array}{l}\text { When a technology falls into the public domain } \\
\text { allowing it to be exploited without the need for } \\
\text { licensing and royalty payments. }\end{array}$ \\
\hline 8 & $\begin{array}{c}\text { Countries where a technology is not protected and } \\
\text { can be exploited freely without infringing the rights } \\
\text { of third parties. }\end{array}$ \\
\hline 9 & $\begin{array}{l}\text { Skills in a given technological field and possibilities of } \\
\text { partnerships. }\end{array}$ \\
\hline 10 & $\begin{array}{l}\text { Market niches, competition movements and players } \\
\text { in a given technological field. }\end{array}$ \\
\hline 11 & $\begin{array}{l}\text { Holders of patent rights for the purpose of licens- } \\
\text { ing, patent portfolio and technological strategies of } \\
\text { companies. }\end{array}$ \\
\hline
\end{tabular}

Source: Machado et al. (2017).

Note that the patent document is the primary source of technological information, which allows knowing new technologies and innovations for the Product Development efficiently (Maleski and Rovai, 2015). Patent documentation must be deposited in the patent offices of the countries where protection is sought. Moreover, it is up to the company to plan in which countries it will grant protection, and the reasons derive from the potentiality of the market, i.e. the company will tend to protect its products and processes in the markets that are relevant, according to its strategies and economic viability to those countries in which it has commercial relation. After the period of secrecy, which corresponds to 18 months, the documents are published and made available for consultation (Teixeira and Souza, 2013). Companies that fail to process patent information or do not protect their innovations by filing patents lose market competitiveness (Trappey et al., 2012; Jeong and Yoon, 2015).

Given the importance of technical knowledge for the company's competitiveness, the protection of property rights is essential to increase the share of profits resulting from technological efforts in highly competitive markets (Pereira and Vasconcellos, 2014). Thus, it is noted that the patent occupying a prominent position is one of the different forms and tools used to protect property rights (Duflou and Verhaegen, 2011). However, using the industrial property system as a competitive intelligence that promotes a business environment conducive to innovation is a complex task and requires integration among all stakeholders of companies to leverage the technological development of their products (Barroso et al., 2009).

\section{Process of Development of Agricultural Machinery}

The product development consists in the accomplishment of a series of tasks, which are characterized by starting in the detection of the business opportunity in the strategic planning, until the launch on target audience (Lizarelli and Toledo, 2016; Silva and Romano, 2016; Silveira et al., 2018). Considering that business practice is usually the result of the characteristics and constraints of the industrial context, it is known that the implementation of improvements is not always an easy task, especially in relation to processes that are often practiced informally (Marini and Romano, 2007; Silveira et al., 2018). For Vernadat (1996), the migration path from the current process to the improved process must begin with questions that need to be answered, including topics related to company strategy, business process reengineering, change management, acquisition knowledge, the design process, and the integration of processes and sub processes.

Figure 1 illustrates the migration path described above, highlighting the role of models in enhancing the product development. According to Vernadat (1996), a model can be used as the basis (ideal model) for the proposal for the formation of other models (Silveira et al., 2017). The modeling of the PDP results in its formalization, that is, in the description of its phases, activities, responsibilities, available re- 
sources, and necessary and/or generated information, promoting the construction of a single shared vision that serves as a common reference for the communication among those listed in the development, allowing better teamwork and management.

From the management it is obtained a structured planning that provides the necessary support to product development and simultaneous engineering, such as how to perform the work among the multiple disciplines involved, integrating product design and manufacturing plan design, reducing time and product cost, and better meeting the expectations of customers (Echeveste et al., 2017; Silveira et al., 2018). The Agricultural Machinery Model was developed with the proposal of structuring the knowledge about product development, providing support for the understanding of the flow and practice and contributing to the companies in the sector to carry out a more formal and systematic development, integrated with other business processes, with suppliers in the supply chain and with final customers (Bergamo and Romano, 2016).

The model is decomposed into three macrophases: planning, project, and validation (Romano, 2013; Silveira et al., 2018). The first macrophase is called "project planning" phase. It involves the delivery of a complete project plan. Subsequently, the following step is the delivery of a sequence of various technical plans relating to specifications, concepts, and plans for the manufacture of the agricultural machine. In the step of the validation the production of the agricultural machinery is structured. It is decomposed into three phases called "production preparation", "launch" and "validation". The main results of each phase include, respectively, product release, initial batch release and project validation (Romano, 2013). Figure 2 shows the graphical structure of the macrophases and their subdivision into four phases. The develop- ment context to reach the objectives of cost, term and manufacturability provides important competitive advantages for the organizations in the context of the companies of agricultural machinery (Romano et al., 2005).

In general, the practices mentioned in the application of information derived from patents are directly connected to the Informational Design phase. This phase is characterized to collect and analyze a set of information that specifies the product with the greatest clarity in order to guide the generation of future project solutions (Romano, 2013). Designing is the second macrophase of the model that begins with the informational design, which is intended to specific the agricultural machines and components and to consolidate the requirements of the customers, from information of sources, such as suppliers, competitors, patents, among others; and unfold them in design specifications. Once the execution of the project plan is started, several tasks are carried out to structure the influence factors (agronomic, mechanical and other specific knowledge - electronics, hydraulics, etc.) (Romano et al., 2005; Silveira et al., 2018). In parallel, marketing planning is continued as the market is monitored to identify variations that may influence the determination of project specifications.

To organize the technical information, the requirements of the customers and/or users are first identified, and these are deployed to the customers' requirements. From the defined customers' requirements, different attributes are considered: functional, ergonomic, safety, reliability, modularity, aesthetic, legal, among others. The next step is to compare specifications of the agricultural machines available in the other organizations, in order to allow the evaluation of the fulfillment of the requirements of the customers and of the design. Figure 3 shows the PDMA Information Design phase and its respective subphases.

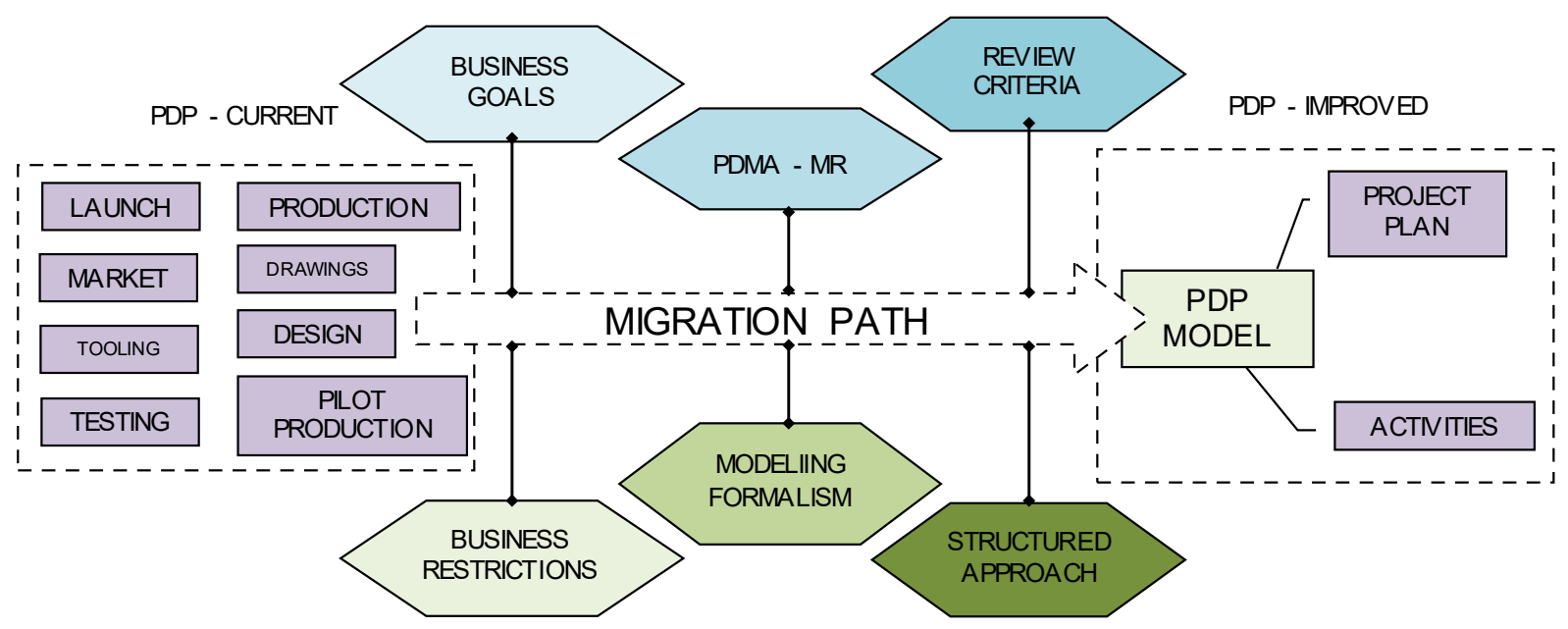

Figure 1. Migration path for PDMA improvement Source: Adapted from Vernadat (1996). 


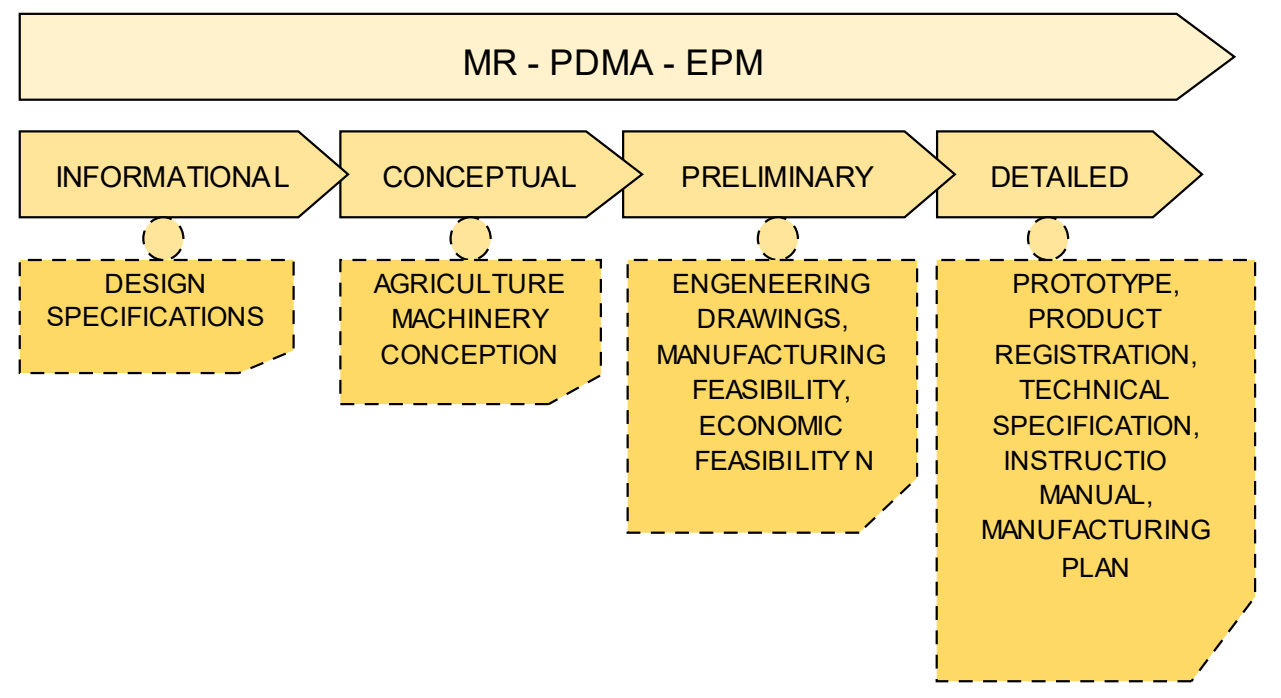

Figure 2. Processes, macrophases, phases, and outputs of the MR-PDMA

Source: Adapted from Romano (2013).

From the requirements derive the project specifications that must be met by the agricultural machinery to be designed (Bergamo and Romano, 2016). With the possession of the specifications, the following is determined: factors of influence in the manufacture plan; the strategy for involving component suppliers; safety information on the life cycle; the goals of dependability; and the target cost of the machine (Romano et al., 2005). Prior to the approval of project specifications, they are assessed for project scope (Romano, 2013; Silveira et al., 2018).

\section{METHODOLOGY}

To reach the objective proposed, it was necessary to delimit it in two stages. Initially, a horizontal scan was made on the literature relevant to the subject of the research and related issues (process of product development and patents), which assisted in the elaboration of a qualitative approach research. Subsequently, a vertical scan was performed to prospect into the articles with scope in the object of the article. The method selected was the Systematic Bibliographic Review (RBS) with recommendation of PRISMA (Main Items for Reporting Systematic Reviews and Meta-analyzes) (Moher et al., 2009; Conforto et al., 2011). In the horizontal scan, three questions were drawn: (1) Define the objective and the research questions; (2) Select keywords and databases; (3) Identify and analyze relevant articles, including the reference model.

The vertical scan had as its objectives: Q1. What are the most commonly used terms in PDMA? Q2. Can the informational design phase be used to list information from patents?
Q3. What are the facilitators, motivations and barriers associated with generating patent information in the context of agricultural machine?

Considering the questions, we proceeded to the step of selecting the keywords and the databases. As a database, Science Direct and ISI Web of Science were selected because of the scope they have in academic research. The following keywords and symbols and Boolean operators were used as the starting point: "agricultural machinery OR product OR product development AND industrial property OR patent OR competitive strategy".

The refinement of the research considered all the years available in the base and adopted the criteria of language (English) and types of documents (article/review). For each article resulting from the search, verification was made to ensure its relevance to the domain of this study and, with the application of the initial filters, 143 articles were identified to be read and analyzed. Considering the searches focused in the selected databases, the research reference points were defined. These reference points compose the synthesis set elaborated on patents and PDMA. A deep analysis of the titles and abstracts was made, extracting 98 articles of the total sample. Subsequently, the reading of the introduction and conclusion was made, and 30 papers were respectively excluded. Thus, 15 articles were used as research material, and they were selected because they contain more details between patents and product development. The RBS methodological flow of the research is shown in Figure 4. 
Brazilian Journal of Operations \& Production Management

Volume 15, Número 4, 2018, pp. 535-544

DOI: 10.14488/BJOPM.2018.v15.n4.a7

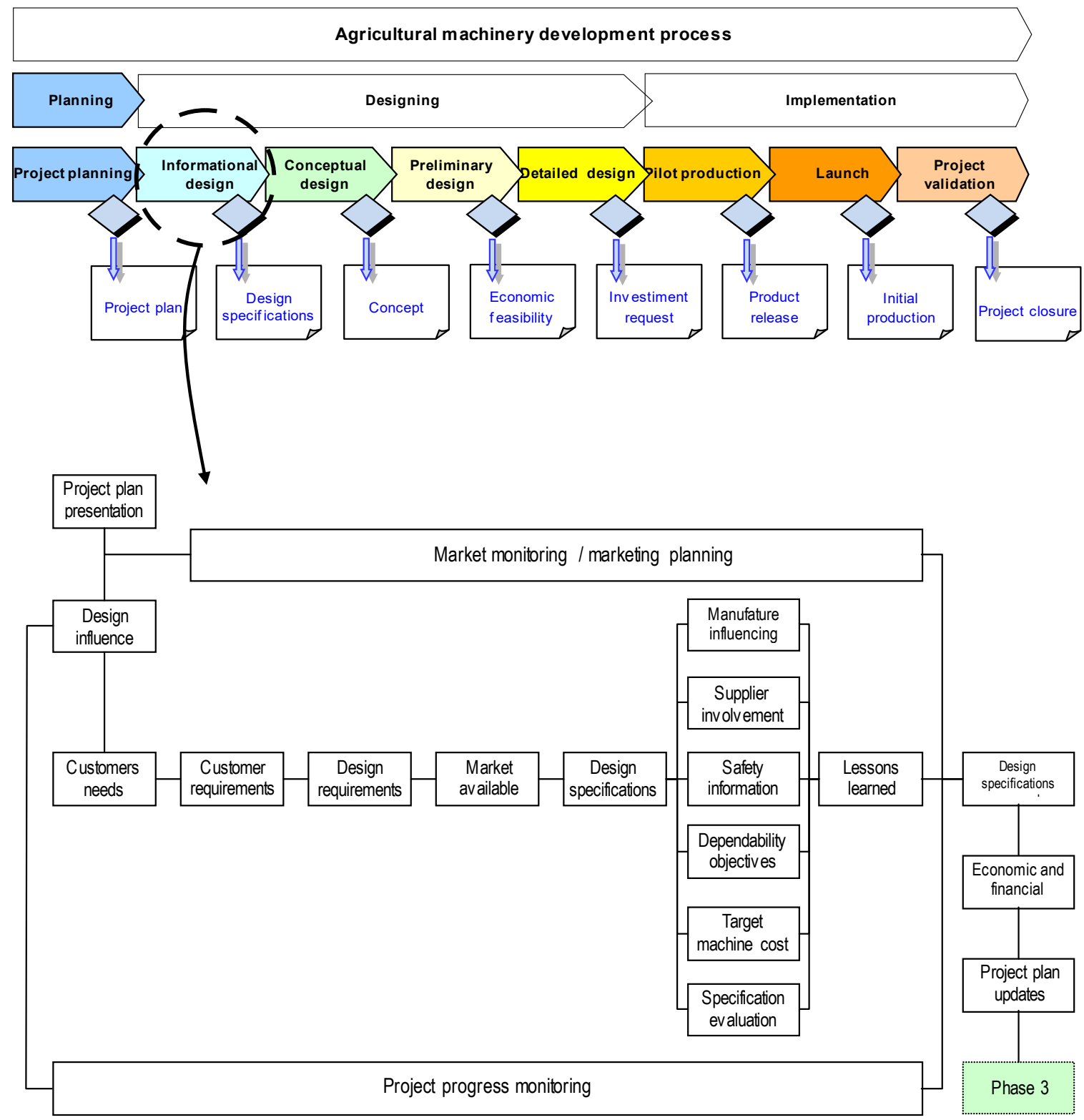

Figure 3. Flow of activities/documents of the informational design phase Source: Adapted from Romano (2013).

Subsequently, the articles from the literature were analyzed, and a synthesis of each one was made, presenting the main characteristics of each one, exposing the vertical sweep and the management model of development. After the literature scans were completed, in the second stage, an exploratory research was adopted using the theoretical-conceptual method, using a machine development structure proposed by Romano et al. (2005), aiming to answer the unfolding of the central question of the relationship between patent and agricultural machinery. A relevant point is the focus to integrate the scientific patent method with the principles of the agricultural machinery development process.

\section{RESULTS AND DISCUSSIONS}

For the presentation of the results of the research, a structure that begins with the consolidation of the main findings of the forms of interaction between patent information and PDMA in elements of exemplifying textual description was chosen, in order to improve the visualizations of the most important aspects of each approach. Afterwards, analyzes are carried out in the development of agricultural machinery, to reflect on the tasks and their allocations in the corresponding phases of the process of development of agricultural machines. It is believed that, in this way, the reading and understanding of the results will be facilitated. 

Brazilian Journal of Operations \& Production Management
Volume 15, Número 4, 2018, pp. 535-544 DOI: 10.14488/BJOPM.2018.v15.n4.a7

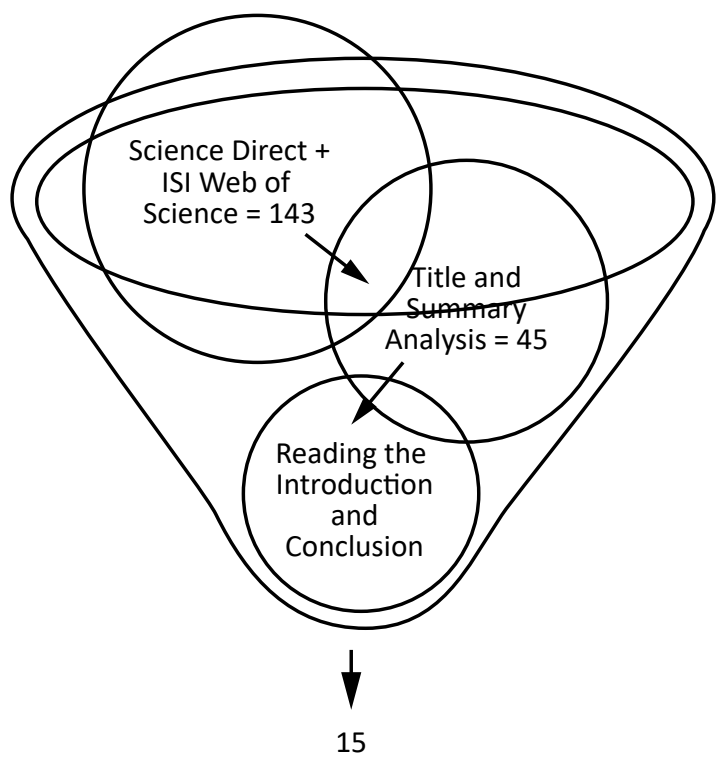

Figure 4. Flow of information with the different phases of RBS

Source: Adapted from Kahmann et al. (2014). Table 2 provides a useful classification by which PDP can be examined in agricultural machines and the developments of this work. This relationship recognizes the considerably different management challenges for the company if it wants to involve the patent in MR-PDMA as a source of technological information. In short, the interaction between patent and MR-PDMA implies proximity between company and technological information. Such a connection increases the chances of success of PDP in agricultural machinery when channeled to the resolution of problems to be addressed through a solution based on new technologies for readjustments and feedback throughout the informational project.

As patent and MR-PDMA information interact, the company reduces its risks and increases its chances of increasing new capabilities, both managerial and technical. As to the detail of the tasks, it is valid to emphasize the unpretentiousness of this article in a short space to identify the whole universe that contributes to the adoption or exploitation of patent information. These tasks, mentioned in Table 2, aim to follow up the theoretical propositions and open new avenues of research. Therefore, brief comments have been made.

According to Table 2, the information coming from the analysis of patents has great flexibility of use. Thus, it has been adapted for several purposes and the MR-PDMA patent framework has the following structure:

a) PDMA Phase: The first layer is related to the product development model that the organization uses to deliver a tangible result of its production process, along with the factors that influence such phase de- liveries, such as the technical specifications of the product.

b) Activity in the PDMA: this search will map, in more detail, what information comes from patents that should compose each aspect of the model, through which the deliveries listed in the first layer can be reached.

c) Suggested tasks: the third layer has the scope of operationally listing the technological resources that must be used to develop mechanisms for delivering technological solutions or objectives (know-how approach). Note that for the correct execution of the tasks, the organization needs a body of professionals with market and business skills, Big Data, including professional skills in prospecting and analysis of patents and articles, and technological surveillance and foresight.

By analyzing Table 2, companies need to systematically and strategically review their intellectual property-related product development activities, involving, among other things, the meaning of the tangible and intangible assets that support the alignment of information derived from such, as legal aspects of patent contracts, talent management for intellectual property, indicators created by competitive intelligence, management of partnerships with partners and registration offices, etc. This systematic evaluation aims to reduce costs, optimize research efforts in the P\&D industry, as well as maximize the productivity associated with the portfolio of patent bases.

In addition to the tasks developed as reported in Table 2, the organization must accredit actions and improvements to be incorporated into the PDMA. Some of the suggested improvements indicated in task points of the company's PDMA flow chart should be introduced, as follows:

a) To carry out regular training for the members of the area of product engineering and manufacturing, dealing with: innovation concepts; technical mechanisms to be used in the PDMA phases; technological prospecting; patents, addressing their types, validity, and requirements.

It has the purpose of dynamizing the knowledge of the organization to corroborate for constructive solutions, increasing the possibility of patentable concepts. Moreover, the training and qualification of these professionals must interact with national and international initiatives. Short and medium term courses and distance education are some of the strategies that can be adopted. They must also implement multiprofessional and interdisciplinary programs that comply with the guidelines recommended by the intellectual property. 
Table 2. The role of patent information in the PDMA

\begin{tabular}{|c|c|c|}
\hline PDMA Phase & PDMA Activity & Suggested Tasks \\
\hline $\begin{array}{l}\text { Informational } \\
\text { Design Phase }\end{array}$ & $\begin{array}{l}\text { Influence Factors in } \\
\text { the Project }\end{array}$ & $\begin{array}{l}\text { i) present more recent information in the agricultural sector, to update state-of-the-art } \\
\text { knowledge; ii) the set of documents in the agricultural sector from several countries } \\
\text { indicates the tendencies of ramification of the development of the PDP area; iii) the use of } \\
\text { technology is not protected and can be exploited freely without infringing the rights of third } \\
\text { parties; and iv) make the product more credible in order to contribute to creating value for } \\
\text { the customer and the company. }\end{array}$ \\
\hline \multirow{4}{*}{$\begin{array}{l}\text { Informational } \\
\text { Design Phase }\end{array}$} & Design Requirements & $\begin{array}{l}\text { i) indicate state-of-the-art evolution and point out R\&D paths, to which resource efforts can } \\
\text { be directed; ii) in technology transfer, the knowledge of patents allows identifying technical } \\
\text { alternatives, as well as of companies qualified in the considered technological sector; and } \\
\text { iii) to protect investment in new technologies, to guarantee profitability superior to the } \\
\text { capital employed in the use of previously used technologies. }\end{array}$ \\
\hline & $\begin{array}{l}\text { Analysis of Machines } \\
\text { Available in the } \\
\text { Market }\end{array}$ & $\begin{array}{l}\text { i) Obtain the priority and concession dates of the patent license, its author, its holder, etc., } \\
\text { allowing verifying if the patent is still in force, and allowing a direct contact for the licensing } \\
\text { of the innovation or, alternatively, to obtain know-how. }\end{array}$ \\
\hline & Safety Information & $\begin{array}{l}\text { i) Obtain information on the practical application of the patent in the industry by describing } \\
\text { the specification, diagrams, and drawings. }\end{array}$ \\
\hline & $\begin{array}{l}\text { Evaluation of Specifi- } \\
\text { cations }\end{array}$ & $\begin{array}{c}\text { i) Obtain technical information in advance from other sources, since the patent is available } \\
\text { before the product is on the market. }\end{array}$ \\
\hline
\end{tabular}

Source: Authors (2018).

b) Technically instruct management and legal levels in filing a patent application as a copyright inhibitor by competition.

Its purpose is to encourage the filing of patents of innovative products or significantly improved by the organization, using judicial and extrajudicial suits. Considering the legal aspects, intellectual property is a branch of Law and contemplates national and international standards, aiming to assure the individual the full use of their inventions, from an industrial and commercial point of view, and, at the same time, to protect these inventions from the action of third parties.

c) To propose visual and three-dimensional techniques for functional modeling of the concept of the product to be proposed, being able to use the FAST method to define, analyze, and understand the functions of the product and the relation between them.

Its purpose is to make the product development team aware of the visual formalization of technical solutions for the prospective customer requirements.

\section{CONCLUSION}

The analyzed theme, that is, the use of patents as a source of technological information in the process of development of agricultural machines, denotes a competitive advantage with the competition. In addition, the research demonstrated the various advantages afforded using intellectual prop- erty rights protection for the agricultural machinery sector. By focusing on the general analysis of the tasks to be developed along the reference model in the PDMA and confining to the context of the informational project, the research brought some evidence on which motivating factors and inhibitors should be observed in order to use the patent as technological information.

It is understood that such patenting tasks can even induce or stimulate industries in the agricultural sector to exploit the technical knowledge contained in patents obtained by third parties as a valuable source of technological information, low cost, and which is capable of feeding a company on its own research and development of new products and processes. However, the isolated reading of a patent will never bring the enlightenment desired by the information professional. One should keep in mind a strategy of electronic manipulation of data in patent collections to extract relevant and consistent information. In this perspective, many universities and research institutions are exercising their role in national development policy, through the application of appropriate knowledge in their faculty, and students due to the needs of access to this knowledge by the private sector, of the government, setting up the Three-Propeller Theory.

In the MR-PDMA model, it is observed that the company that has a formal systematization of product development combined with efficient information capture and influence factors will be able to obtain a competitive advantage, being provided to companies with high degree of technology and innovation, whether obtained at their own expense or through partnerships with universities. Finally, it is im- 
portant to prioritize the protection of intellectual property rights, since intangible assets are also considered as indicators of technological innovation because they constitute a differential that contributes to the competitive advantage.

It was observed that, in general, the advantages of using patent information are the generation of opportunities to expand the possibilities of proposing new concepts of agricultural machinery, including technologies that comply with the precepts of Industry 4.0 and autonomous vehicles, aiming at expanding business markets by building effective partnerships, valuing the reputational capital of companies and the systematic monitoring of competitors.

For future research, further studies are suggested to verify the operational interaction between the MR-PDMA and the economic and technical advantages resulting from these actions for the various business segments, both the $R \& D$ sector and in the management part strategy. It is also regarded as relevant the investigation of the perspectives of the various actors that are members of the value stream of the adopting company, structuring the systematization of lessons learned throughout project management. A comparison between the MR-PDMA patent proposals focused on the four dimensions proposed by the Oslo Manual (2005) is also suggested. They are: product/service innovation, process innovation, marketing innovation, and organizational innovation. In this context, the articulation and coordination of actions between the various research institutions and actors that compose the business system, together with the strategies and policies of organizational patentability, stand out.

\section{REFERENCES}

Barroso, W.; Quoniam, L.; Pacheco, E. (2009), "Patents as technological information in Latin America", World Patent Information, Vol. 31, No. 3, pp. 207-215.

Bergamo, R. L.; Romano, L. N. (2016), “Agricultural machinery and implements design process: guidelines for small and mid-sized businesses", Engenharia Agrícola, Vol. 36, No. 1, pp. 206-216.

Carrara, P.; Russo, D. (2017), “Patent searches opinion: How to minimize the risk when reviewing patent applications", World Patent Information, Vol. 49, pp. 43-51.

Choi, D.; Kim, Y. (2017), “Market share and firms' patent exploitation", Technovation, Vol. 72-73, pp. 13-23.

Conforto, E. C.; Amaral, D. C.; Silva, S. L. (2011), “Roteiro para Revisão Bibliográfica Sistemática: Aplicação no Desenvolvimento de Produtos e Gerenciamento de Projetos", in: 8o Congresso Brasileiro de Gestão de Desenvolvimento de Produto - CBGDP, Porto Alegre, RS, Instituto de Gestão de Desenvolvimento do Produto - IGDP. Anais... Porto Alegre: IGDP.
De-Carli, E.; Segatto, A. P.; Alves, F. S. et al. (2017), “Characterization on the patents deposits from Public Research Institutes of Brazil from 2004 to 2013", Revista de Admnistração e Inovação, Vol. 14, No. 2, pp. 168-177.

Di Blasi, G. (2005), A propriedade intelectual: os sistemas de marcas, patentes e desenhos industriais a partir da Lei $\mathrm{n}$ 9.279, de 14 de maio de 1996, Forense, Rio de Janeiro.

Duflou, J. R.; Verhaegen, P. A. (2011), "Systematic innovation through patent based product aspect analysis", CIRP Annals, Vol. 60, No. 1, pp. 203-206.

Echeveste, M. E. S.; Rozenfeld, H.; Fettermann, D. C. (2017), "Customizing practices based on the frequency of problems in new product development process", Concurrent Engineering, Vol. 25, No. 3, pp. 245-261.

Ferreira, A. A.; Guimarães, E. R.; Contador, J. C. (2009), “Patente como instrumento competitivo e como fonte de informação tecnológica", Gestão \& Produção, Vol. 16, No. 2, pp. 209-221.

Gama, F.; Amboni, N.; Alperstedt, G. D. et al. (2016), “Processo de captação de novas oportunidades no desenvolvimento de novos produtos em uma empresa industrial de motores elétricos", Gestão \& Produção, Vol. 23, No. 3, pp. 459-472.

Jeong, Y.; Yoon, B. (2015), “Development of patent roadmap based on technology roadmap by analyzing patterns of patent development", Technovation, Vol. 39-40, pp. 37-52.

Jou, J. B. (2018), "R\&D investment and patent renewal decisions", The Quarterly Review of Economics and Finance, Vol. 69, pp. 144-154.

Kahmann, A.; Kloeckner, A. P.; Zocche, L. et al. (2014), “Teoria das Restrições e Gestão de Projetos - Corrente Crítica: Uma Revisão Sistemática de Literatura", Espacios, Vol. 35, No. 13, pp. 3.

Kim, M.; Parque, Y.; Yoon, J. (2016), “Generating patent development maps for technology monitoring using semantic patent-topic analysis", Computers \& Industrial Engineering, Vol. 98, p. 289-299.

Livotov, P. (2015), “Using Patent Information for Identification of New Product Features with High Market Potential", Procedia Engineering, Vol. 131, pp. 1157-1164.

Lizarelli, F. L.; Toledo, J. C. (2016), “Práticas para a melhoria contínua do Processo de Desenvolvimento de Produtos: análise comparativa de múltiplos casos", Gestão \& Produção, Vol. 23, No. 3., pp. 535-555.

Machado, F. M.; Ortiz, L. C. V.; Silveira, F. et al. (2017), “A Patente como Fonte de Informação Tecnológica no Desenvolvimento de Máquinas Agrícolas. Propriedade Intelectual e Transferência de Tecnologias", in III ENPI: Encontro Nacional de Propriedade Intelectual, Santo Ângelo, RS, 18-19 maio 2017. 
Brazilian Journal of Operations \& Production Management Volume 15, Número 4, 2018, pp. 535-544

DOI: 10.14488/BJOPM.2018.v15.n4.a7
Maleski, S.; Rovai, R. L. (2015), “Desenvolvimento de projeto de novos produtos com base na triz: estudo de caso na indústria automobilística", Journal of Innovation, Projects and Technologies, Vol. 3, No. 2., pp. 197-210.

Organização para a Cooperação e Desenvolvimento Econômico - OCDE (2005), Manual de Oslo: proposta de diretrizes para coleta e interpretação de dados sobre inovação tecnológica, 3. ed., OECD.

Maresch, D.; Fink, M.; Harms, R. (2016), "When patents matter: The impact of competition and patent age on the performance contribution of intellectual property rights protection", Technovation, Vol. 57-58, pp. 14-20.

Marini, V. K.; Romano, L. N. (2007), "The function structure as a tool for analysing an existing concept of a centrifugal fertilizer spreader", Product, Vol. 5, No. 2, pp. 77-89.

Mayerhoff, Z. (2007), Busca da Informação Tecnológica, Transparências de aula, INPI, Rio de Janeiro.

Moher, D.; Liberati, A.; Tetzlaff, J. et al. (2009), "Preferred Reporting Items for Systematic Reviews and Meta-Analyses: The PRISMA Statement", PLoS Medicine, Vol. 6, No. 7, e1000097.

Pereira, F. C.; Costa, H. G.; Pereira, V. (2017), “Patent filings versus articles published: A review of the literature in the context of Multicriteria Decision Aid", World Patent Information, Vol. 50, pp. 17-26.

Pereira, H. M. S.; Vasconcellos, E. P. G. (2014), “Differences in the patent management in Brazilian companies with and without plants abroad", Revista de Admnistração, São Paulo, Vol. 49, pp. 625-641.

Sheau-Pyng, J.; Ming-Fong, L.; Chin-Yuan, F. (2012), "Using Patent Analysis to Analyze the Technological Developments of Virtualization", Procedia - Social and Behavioral Sciences, Vol. 57, pp. 146-154.

Romano, L. N. (2013), “Desenvolvimento de Máquinas Agrícolas: planejamento, projeto e produção", Blucher Acadêmico, São Paulo.
Romano, L. N.; Back, N.; Ogliari, A. et al. (2005), “An Introduction to The Reference Model for the Agricultural Machinery Development Process", Product, Vol. 3, No. 2, pp. 109132.

Sichelman, T. (2010), "Commercializing patents", Stanford Law Review, Vol. 62, No. 2, pp. 341-414.

Silva, J. R.; Romano, L. N. (2016), "Fluxo de informações administrativa-financeira no processo de desenvolvimento de máquinas agrícolas", Espacios, Vol. 37, No. 23, pp. 6.

Silveira, F.; Machado, F. M.; Ruppenthal, J. E. et al. (2018), "Systematic analysis of reference models in product development: case studies in the agricultural machinery and implementation sector", Independent Journal of Management \& Production, Vol. 9, No. 2., pp. 395-423.

Silveira, F.; Machado, F. M.; Ruppenthal, J. E. (2017), Processo de Desenvolvimento de Máquinas Agrícolas, Novas Edições Acadêmicas, Saarbrücken.

Teixeira, R. C.; Souza, R. R. (2013), “O uso das informações contidas em documentos de patentes nas práticas de Inteligência Competitiva: apresentação de um estudo das patentes da UFMG", Perspectivas em Ciência da Informação, Vol. 18, No. 1, pp. 106-125.

Trappey, A. J. C.; Trappey, C. V.; Wu, C. et al. (2012), “A patent quality analysis for innovative technology and product development", Advanced Engineering Informatics, Vol. 26, No. 1, pp. 26-34.

Turner, J. L. (2018), "Input complementarity, patent trolls and unproductive entrepreneurship", International Journal of Industrial Organization, Vol. 56, pp. 168-203.

Vernadat, F. B. (1996), Enterprise modeling and integration: principles and applications, Chapman \& Hall, London.

Received: 15 Jun 2018

Approved: 17 Aug 2018

DOI: 10.14488/BJOPM.2018.v15.n4.a7

How to cite: Silveira, F.; Machado, F. M.; Romano, L. N. et al. (2018), "Strategy for the Development of Agricultural Machinery: Importance of Patent Analysis", Brazilian Journal of Operations \& Production Management, Vol. 15, No. 4, pp. 535-544, available from: https://bjopm.emnuvens.com.br/bjopm/article/view/513 (access year month day). 